Reseña

\section{Rafael Vallejo y Carlos Larrinaga (dirs.). Los orígenes del turismo moderno en España. El nacimiento de un país turístico 1900-1939. Madrid, Sílex Ediciones, 2018, 1006 pp. ISBN: 978-8477376897.}

A día de hoy nadie cuestiona que uno de los principales motores de cambio del siglo xx en España ha sido la industria turística. Lejos, aunque muy presentes, aún tenemos las palabras del que fue secretario de la Cámara de Comercio de Mallorca, Bartomeu Amengual Andreu (1866-1961), cuando en 1903 publicó La industria de los forasteros, texto que con los años se ha convertido en referente bibliográfico para los investigadores de la historia del turismo, pues en su análisis Amengual ya animaba a dar pasos en la organización del turismo en España tal y como llevaban a cabo otros países europeos como Suiza, Italia o Austria.

Es precisamente a finales del siglo xIx e inicios del siglo $\mathrm{xx}$ cuando se empezará a hablar y a generar un debate sobre la idoneidad o no de fomentar esta industria. Dentro de las diferentes personas que analizan y plantean este debate queremos recordar a Miquel dels Sants Oliver (1864-1920). Periodista, escritor y director de los periódicos La Almudaina (Palma), Diario de Barcelona y La Vanguardia, en 1890 ya plantea un análisis comparativo entre el turismo europeo y el modelo económico, llegando a afirmar que la industria turística, además de dinamizar el ámbito económico, podría ser un instrumento modernizador en todos los ámbitos. Oliver incluso es uno de los primeros que habla de lo que supone la innovación y el ocio para las sociedades modernas.

Es en este contexto de inicios de siglo xx cuando situamos el punto de partida de las diferentes investigaciones que encontramos en la obra Los orígenes del turismo moderno en España. El nacimiento de un país turístico 1900-1939, dirigida por Rafael Vallejo y Carlos Larrinaga. Queremos señalar que estamos delante de una gran obra colectiva, ambiciosa e interdisciplinar, que ha sido llevada a cabo por veintidós investigadores que han analizado y reflexionado en torno al nacimiento de nuestra industria turística en un momento histórico donde ya se ha apostado por esta nueva fuente económica.

Todos los trabajos recogidos en este libro han sido realizados por investigadores de reconocido prestigio en la historia del turismo. Un ámbito de conocimiento de la historia contemporánea en el que en estos últimos años se ha avanzado considerablemente y que, con la aportación de esta obra lo hace aún más, ya que, como explican sus directores, el objetivo es ofrecer una visión actualizada de los orígenes del turismo moderno en España en los primeros cuarenta años del siglo xx. Es por ello que este trabajo también ha servido para repensar muchos de los aspectos históricos del turismo, cosa que ha permitido realizar una mayor contextualización del mismo.
Pero, además, hablamos de que este libro llena un gran vacío historiográfico, ya que supone un gran reto desde sus inicios. De hecho, podemos constatar que diversos autores han hecho uso de nuevas fuentes y nuevas herramientas en su investigación, ya que pretendían dar respuesta a muchas preguntas y temas pendientes. De todas estas nuevas aportaciones resulta fundamental remarcar el uso que se ha hecho de la prensa histórica digitalizada, lo que constituyendo su explotación una novedad en el tema, que ha permitido obtener y generar datos inexistentes hasta día de hoy.

Y es que hay que tener en cuenta que, a través del análisis de esta obra, el lector podrá conocer muchos de los aspectos que engloban la realidad turística española en un momento crucial como es el comprendido entre 1900 y 1939. Un periodo que sienta unas bases económicas, políticas y sociales determinantes de cara al devenir futuro de nuestro turismo.

La obra, estructurada en siete grandes secciones, comienza con un análisis general del origen del turismo moderno en España a cargo de Rafael Vallejo y Carlos Larrinaga, donde se nos ofrece una perspectiva general turística del periodo cronológico que comprende la obra. Además de esta presentación también queremos destacar el trabajo del especialista Sasha D. Pack sobre las múltiples caras del turismo en la Europa contemporánea.

Queremos también poner de relieve la evolución de los diferentes desarrollos regionales, tema trabajado por Rafael Vallejo, y que sin duda en el futuro arrojará más información con sucesivas investigaciones, pues queda mucho trabajo que realizar. En la obra también se analiza todo el esquema de la geografía turística estudiado por Carmen Gil. Muy importantes y destacados son los capítulos de Rafael Vallejo, Elvira Lindoso y Margarita Vilar, que engloban el ámbito económico, tanto en lo que respecta a la demanda como a la oferta turística.

Los capítulos relacionados con las diferentes políticas turísticas de esta etapa han sido trabajados por Ana Moreno, Carmelo Pellejero, Rafael Vallejo, Eva Concejal, Saida Palou y María Velasco, y permiten conocer la postura adoptada por las diferentes Administraciones públicas en temas muy diversos que conciernen al periodo de análisis.

En este contexto inicial es obligado hablar de la creación de la Comisión Nacional de Turismo, según Real Orden del 6 de octubre de 1905, primer órgano público español encargado de fomentar en España las excursiones artísticas y de ocio para el público extranjero. Además, debemos tener en cuenta los trabajos que llevaría a cabo la sucesiva Comisaría Regia de Turismo, los diferentes patronatos nacionales de turismo o el Servicio Nacional de Turismo, instituciones estatales todas estas encargadas de regular y administrar el tema turístico dentro del marco cronológico objeto de estudio.

Otra de las secciones que adquiere un papel destacado en este libro es el de la publicidad, la promoción y la imagen tu- 
rística. En este sentido encontramos trabajos relacionados con el ámbito de la publicidad en la construcción de la imagen de España como los de Beatriz Correyero y Kirsty Hooper, o el de la prensa especializada de viajes y turismo de Eva Concejal. En este apartado juega un papel fundamental el hecho de entender el trabajo que se ha llevado a cabo tanto desde el sector público como privado en la configuración de la imagen de España y sus respectivos destinos regionales. Precisamente, el tema de las organizaciones turísticas privadas y sus trabajos de promoción ha sido trabajado en el libro por Carmelo Pellejero y Marta Luque.

No en balde, la defensa y promoción de este turismo extranjero, es decir, de hacer tours o circuitos turísticos, adquiriría un papel importante por la iniciativa que estaban desarrollando algunas asociaciones turísticas sin ánimo de lucro. En este sentido, se deben mencionar las tareas que hacían los sindicates d'iniciative y los touring club.

La evolución de los transportes y el sector turístico es un bloque que han trabajado Rafael Barquín y Javier Vidal. Resulta fundamental el papel inicial del ferrocarril, si bien también se deben considerar otros sistemas como el automóvil y la aviación. Cabe tener en cuenta que en estos años el hecho de poder realizar estos desplazamientos estaba condicionado a poder ofrecer unos servicios de transporte.

El sector hotelero, la formación de las primeras cadenas hoteleras y el papel de las agencias de viajes son aspectos importantes de esta etapa de inicios de siglo xx y analizados por Carlos Larrinaga y Rafael Vallejo. Una aportación muy importante en este campo y una línea de trabajo que continuar.

Las diferentes modalidades que permite el sector turístico de estas primeras décadas del siglo xx son aspectos que encontramos en los capítulos finales de esta obra. Debemos mencio- nar el trabajo realizado por Margarita Vilar-Rodríguez y Elvira Lindoso-Tato sobre el turismo de salud y la oferta balnearia; el turismo marítimo entre 1900 y 1936 que ha estudiado Gaetano Cerchiello; los primeros pasos en un turismo relacionado con los espacios naturales de Andrés Sánchez y José Joaquín García o todo lo relacionado con el turismo religioso englobando fiestas patronales, Semana Santa, santuarios y peregrinaciones, análisis que hace Xosé M. Santos.

Esta extensa y voluminosa obra concluye con un trabajo de Saida Palou sobre el turismo urbano y el papel de las ciudades; la arquitectura de las aguas en el turismo de María A. Leboreiro, y sobre el nacimiento de una red pública de alojamientos turísticos como los paradores, las hosterías, los refugios y los albergues, análisis que realiza María José Rodríguez.

En resumen, estamos delante de una gran obra que pone de relieve la importancia gradual que adquirió el fenómeno turístico desde un punto de vista moderno en el primer tercio del siglo xx. Una actividad turística que no parará de crecer y consolidarse hasta bien entrados los años treinta. El estudio de esta etapa resulta indispensable para poder entender el devenir turístico que tendrá lugar después del periodo bélico. La calidad de los trabajos aquí reunidos, así como el uso de nuevas fuentes y herramientas utilizadas para su elaboración, resultan algunas de las aportaciones más importantes de este libro de referencia que, sin duda, aporta mucha luz a la historia de nuestro turismo.

Antoni Vives Reus

Centro de Enseñanza Superior Alberta Giménez Universidad Pontificia de Comillas

https://doi.org/10.33231/j.ihe.2020.12.014 